\title{
Effects of Graphite Particle Size on Microstructure and Properties of In-situ Ti-V Carbides Reinforced Fe-based Laser Cladding Layers
}

\author{
Hui Zhang ${ }^{1,2, *}$, Dongting $\mathrm{Wu}^{3}$, Tao Luan ${ }^{1}$, Guangchun Xiao ${ }^{2}$, Wei Zhao ${ }^{2}$, \\ ${ }^{1}$ School of energy and power engineering, Shandong University, Jinan, China \\ ${ }^{2}$ College of mechanical and automotive engineering, Qilu University of Technology (Shandong \\ Academy of Sciences), Jinan, China \\ ${ }^{3}$ School of materials science and engineering, Shandong University, Jinan, China \\ *E-mail: zhanghui198787@163.com
}

doi: $10.20964 / 2019.03 .60$

Received: 4 November 2018 / Accepted: 22 December 2018 / Published: 7 February 2019

The effects of graphite particle size on the microstructure, hardness and corrosion resistance of in-situ TiC-VC reinforced Fe-based laser cladding layers were studied. Results indicated that the corrosion resistance of the $\mathrm{TiC}-\mathrm{VC} / \mathrm{Fe}$ laser cladding layers could be improved by optimizing the graphite powder particle size. As the graphite particle size decreased from $180-270 \mu \mathrm{m}$ to $1.3 \mu \mathrm{m}$, the average particle size of carbide decreased from 1.73 to $0.46 \mu \mathrm{m}$ and the microstructure transformed from plate martensite into lath martensite, and finally into granular bainite. The hardness of the cladding layers decreased about $130 \mathrm{HV}_{0.2}$, but the corrosion resistance increased. The cladding layer prepared with a graphite particle size of $1.3 \mu \mathrm{m}$ showed the best corrosion resistance, which was about 3.80 times greater than that of the cladding layer prepared with a graphite size of $180-270 \mu \mathrm{m}$.

Keywords: graphite particle size; corrosion resistance; laser cladding; TiC-VC

\section{$\underline{\text { FULL TEXT }}$}

(C) 2019 The Authors. Published by ESG (www.electrochemsci.org). This article is an open access article distributed under the terms and conditions of the Creative Commons Attribution license (http://creativecommons.org/licenses/by/4.0/). 